\title{
Libraries and Archives in the Former Han Dynasty (206 BCE-9 CE): Arguing for a Distinction
}

\begin{abstract}
The imperial collection of the Former Han dynasty, the oldest Chinese manuscript collection of which we possess a catalogue, has both been called an archive and a library. This paper discusses the fundamental difference between an archive and a library in the manuscript age. On the basis of this distinction, it argues for the imperial collection to be identified as a library and provides evidence of a clear distinction between 'archive' and 'library' in this period of Chinese history.
\end{abstract}

\section{Introduction}

The imperial collection of the Former Han dynasty (206 BCE-9 CE) is the oldest Chinese manuscript collection about which we have detailed information in the form of a catalogue. This catalogue, in turn, has come down to us in the form of a chapter in the History of the Han (Hanshu 漢書) entitled Treatise on Classics and other Texts (Yiwenzhi 藝文志). ${ }^{1}$ As is well known, the compiler of the History, Ban Gu 班固 (3292), shortened an earlier catalogue for the Treatise composed by Liu Xin 劉歆 (c.50 BCE-23 CE), but this earlier version has now been lost. The former catalogue known as Seven Epitomes (Qilüe 七略) was based on elaborate editorial reports, most of which have also been lost. These were written down as part of the grand collation project initially headed by Liu Xin's father, Liu Xiang 劉向 (79-8 BCE) and continued by the son after the latter's death. This project, which began in $26 \mathrm{BCE}$, aimed at assessing the holdings at the imperial court, but also included major editorial work. It signifies a crucial point in the history of most if not all early Chinese literature, because it involved the fixation of editions and documentation of these.

Researchers variously refer to this manuscript collection as a 'library' or 'archive'. Scholars working in the field of library history generally label the collection a library or even the first library in Chinese history. ${ }^{2}$ Those working on the history

1 HS 30:1701-1781.

2 This is true of Western scholarship (e.g. Koh Thong-ngee 1964, 40; Drège 1991, 19-24; Lewis 1999, 325-331; Dudbridge 2000, 5-6), but also of Chinese scholarship, where we have a few arti-

https://doi.org/10.1515/9783110541397-007, (c) BY-NC-ND () 2018 M. J. Fölster, published by De Gruyter. This work is licensed under the Creative Commons Attribution-NonCommercial-NoDerivs 3.0 License. 
of archives, on the other hand, tend to identify it as an archive. ${ }^{3}$ One reason for this is the often repeated argument that there was no clear distinction between the two in early China; the same places are said to have been used to store documents and literary or historical works. ${ }^{4}$ It is typically argued that the archive came first and the library gradually developed out of this. ${ }^{5}$ There seems to be no general consensus regarding what point in time a clear distinction is possible. To some, this division can only be made fully with the introduction of printed books in the tenth century CE. ${ }^{6}$ This obviously is based on modern notions, according to which libraries keep published and thus printed books, while archives store what is unpublished and thus not printed. This is a concept that is clearly unsuitable for the pre-printing age, though.

Essentially, this is a problem of definition. Most of the above-mentioned scholars do not define their use of the terminology; they use the modern terms without giving much thought about either their origins or the concepts behind them. To begin with, there was no genuine term for 'library' in the Han era. The modern word for 'library', tushuguan 圖書館, was adopted as a loanword from Japanese in the late nineteenth century to denote modern public libraries. ${ }^{7}$ Older terms, such as cangshulou 藏書樓 (lit. 'book collecting building'), cangshushi 藏書室 (lit. 'book collecting chamber'), shuku 書庫 (lit. 'book repository') and wenku 文庫 ('literature repository') did not exist in Han times, but were introduced later. ${ }^{8}$ Some scholars,

cles specifically devoted to libraries under the Han (Chiang 1963; Lu Hesheng 1983; Wang Qiming 2003) and, of course, standard library histories such as Xie Zhuohua 2005, 45-64 and Ren Jiyu 2001, 382-390.

3 Again, there are a number of specialized articles on Han archives (Li Deyun 1980; Huang Caigeng 1988; Zhang Wei 1992) as well as standard works on the history of the archive in China (e.g. Zou Jiawei/Dong Jian 1985, 33-34; Zhou Xueheng 1994, 124-127).

4 Zhang Wei 1992, 49-50; Zhang 2004, 25. Based on this assumption, Nylan 2014 puts forward the argument that Liu Xiang's collation project, which eventually led to the compilation of the catalogue of the imperial collection, was a 'conversion of part of the administrative archives into a real library' (160).

5 Di Chongde/Chen Bolan 1981. The same argument is also made about the emergence of the library in the West: see Harris/Johnson 1999, 14. To me, it is questionable whether using the term 'archive' is appropriate. It would seem advisable to use a third term such as 'repository' or 'storage room' from which a distinction between 'library' and 'archive' evolved.

6 Drège 1991, 84.

7 Wu Xi 1996, 9-10. Wu purports that the term was first used by Liang Qichao 梁啟超 in 1896. Many new terms for Western ideas and concepts were imported into China from Japan in this period; see Amelung/Kurtz/Lackner 2001.

8 According to Wu Xi 1996, 9-10, cangshulou first appeared in Tang times (seventh-tenth century $\mathrm{CE}$ ) and was initially only used to refer to private collections. For a preliminary list of terms used for libraries throughout Chinese history, which I put together myself, see Delhey/Lorusso 2015, 4-8. 
like $\mathrm{Wu} \mathrm{Xi}$ and P. A. Herbert, make a sharp distinction between the modern library (tushuguan) as opposed to the traditional library (cangshulou), and Wu Xi even comes to the conclusion that China did not have any libraries at all prior to the introduction of the modern public library. According to them, the main difference is that the modern public library aims to make books available to everyone, while the traditional Chinese library aims to store and preserve books. ${ }^{9}$ The traditional library is thus very close to a mere repository. The dichotomy of traditional versus modern also denies any kind of development prior to the introduction of the modern concept, which surely is oversimplifying things.

The picture is somewhat different in the archive's case. As will be shown later, a genuine term for 'archive' did indeed exist in Han times. However, it is not the same as the modern word for 'archive', dang'an 檔案 (dang'anguan 檔案館 or dang'anku 檔案庫 for the place). It is a fact that dang'an was first employed during the Qing dynasty (1644-1911), as it does not appear in any sources prior to 1638. Whether the term also has its origin in the Manchu language is contested, though. ${ }^{10}$ Archival practices in the Qing period nonetheless differ from the modern European archival concepts. Like the case of the library in China, what is found to be characteristic of the traditional Chinese archive is its mere storage function and a lack of systematic organization for the purpose of retrieval. At the same time, it is argued that the state, which was the dominating force in archival preservation, was more interested in controlling historical records than preserving them; there was no special interest in keeping original documents. According to Western scholarship, premodern Chinese archives completely served the needs of official historiography. As soon as official historical compilations were put together, the original documents were of no interest anymore and were simply destroyed. ${ }^{11}$

As already mentioned above, the modern notion of the difference between 'library' and 'archive', which is based on the physical appearance of the objects found in a collection, is not suitable for understanding the situation for the age prior to

9 Wu Xi 1996, 1-2; Herbert 1980, 120-121.

10 Fitzgerald 2015 argues that it stems from the Manchu dangse with the meaning 'wood on which a document is written' (77). Because of the shortage of paper, the Manchu had used wooden slips for their administrative documents. Later, the term supposedly fused with the Chinese an. Zhao Zhiqiang 2016 summarizes the various explanations of the origin of the word. Basing his thinking largely on linguist grounds, Zhao comes to the conclusion that the term rather stems from older Chinese words. Also see Wagner 2006, 28 (Wagner 2004 is basically identical to the introduction in Wagner 2006).

11 Wagner 2006, 27-29; Ye/Esherick 1996, 4-5. It should be noted that the main focus of the two studies is on archives in the People's Republic of China. They only deal with traditional archives as precursors to the modern archive. 
the invention of printing technology. In our case, it is worth looking at how disciplines dealing with ancient manuscript cultures other than that of China have discussed this issue. Due to the rather imperishable nature of clay tablets, the field of Assyriology is in the fortunate position of being able to work with numerous extant collections. Although scholars have lamented about a similar confusion concerning the use of the two terms in question, they have made a considerable effort to distinguish between 'library' and 'archive'. In the 1950s, Mogens Weitemeyer differentiated them according to the function and content of a particular collection, for instance:

[...], a distinction between library (bibliothèque) and archive must be considered practical, seeing that they differ essentially in their functions. An archive consists of a collection of documents drawn up and used in some administrative, legal or economic process and forming part of the same; [...]. [...]. While the archive contains documents recording phenomena of material life, the library holds products of the mental activity of man: a library is a collection of works (religious, literary, mathematical, legal, philological, etc.) gathered with a view to immediate or later use by the group of persons served by the library. ${ }^{12}$

In a more recent study, Olaf Pedersén has drawn a similar distinction between the two, adding that even in the age prior to the invention of mechanical reproduction, the number of copies of a text in a collection may be regarded as a further point of distinction:

The term 'archive' [...] refers to a collection of texts, each text documenting a message or statement, for example, letters, legal, economic, and administrative documents. In an archive there is usually just one copy of each text, although occasionally a few copies may exist. 'Library', on the other hand, denotes a collection of texts normally with multiple copies for use in different places at different times, and includes, e.g. literary, historical, religious, and scientific texts. In other words, libraries may be said to consist of the texts of tradition. With rather broad definitions of the terms 'document' and 'literary text', it may be simplest to say that archives are collections of documents and libraries are collections of literary texts. ${ }^{13}$

At the same time, Pedersén is aware of the possibility that both types may be found in one and the same collection. However, in his analysis of 253 collections, he found that only 27 (11\%) were of the mixed kind. In all the other cases, a clear distinction was possible based on the content. ${ }^{14}$

Further research on the topic of the archive in ancient times stresses that '[a]rchives were not merely a storage place for "all kinds of records". Rather, it

12 Weitemeyer 1956, 218.

13 Pedersén 1998, 3.

14 Pedersén 1998, 278-280. 
is evident that documents placed in an archive were specifically selected for retention. Documents must have been classified by different types, and a selection of these made to identify those for storage'. ${ }^{15}$ The same argument is also made about the library: 'Libraries are not simply storehouses of books. They are the means of organizing knowledge ... of controlling that knowledge and restricting access to it'. ${ }^{16} \mathrm{~A}$ certain degree of organization is what essentially differentiates both libraries and archives from incidental assemblages of manuscripts. What obviously differentiates the two from each other is their function, which is reflected in the different types of texts found within them.

\section{The imperial collection of the Former Han}

Turning to the Han dynasty's imperial collection, one of the first things that are apparent about it is that unlike the collections Assyriologists deal with, it is a collection that has completely vanished. Very few manuscripts were discovered during the archaeological excavation of Weiyang Palace in Chang'an 長安, the capital of the Former Han, which took place in the 1980s. Only 115 wooden slips were unearthed, most of which were severely damaged and all of which had been burnt. According to Xing Yitian's research, they largely contain records of various benevolent omens. He links the scorch marks to the pillaging of Chang'an by Red Eyebrows rebels in $25 \mathrm{CE}$. This rebellion is also believed to have inflicted major damage on the imperial collection. ${ }^{17}$ Although the Treatise on Classics and other Texts (hereafter: Treatise) does include titles with reference to omens and both Liu Xiang and Liu Xin are known to have written about and used omenology, it is unlikely that these slips once were part of the imperial collection, because they were not found at the site identified as the place mentioned in historical sources where the collection is said to have been kept. ${ }^{18}$ In recent decades, numerous

15 Brosius 2003, 6.

16 Harris/Johnson 1999, 6 quoting Mary Beard (London Review of Books, Feb. 1990, 11). Jacob 1998, 94 equally stresses that it is not just the accumulation of books, but the classification of them that defines a library.

17 Xing Yitian 2011a. For details of the Red Eyebrows, see HS 99B:4193 and Bielenstein 1959, 91-102.

18 The Treatise includes Divine Communication (Shenshu 神輸, see HS 30:1703), which according to a text fragment of Liu Xiang's editorial report talks about the link between the emperors' conduct and the emergence of calamities and propitious omens (cited in commentary by Yan Shigu, HS 30:1704). There are five other titles with reference to baleful omens (zaiyi 災異); see HS 30:1703, 1768. On Liu Xiang's use of omenology, see Yang 2015. The place most directly linked to the collation project is the Celestial Deer Pavilion (Tianluge 天祿閣/天鹿閣). This is probably 
manuscripts have been brought to light dating to the pre- and early imperial period (roughly the fifth century BCE to third century $\mathrm{CE}$ ). However, none of these were found in the core regions of the Han Empire, but in its outer periphery to the north and south. Hence, it can be ruled out that they once belonged to the imperial collection. ${ }^{19}$

Although none of the manuscripts in the imperial collection have survived the ravages of time, and even though well over 80 per cent of the catalogue's 631 entries are only known by their title, ${ }^{20}$ the Treatise nonetheless tells us exactly what kind of texts the collection once contained. More importantly, we can also tell what was not in the collection from the little information we do possess.

Apart from an introductory section at the beginning of the Treatise, it is basically a classified catalogue divided into six main categories and 38 sub-categories. The six main categories are as follows:

1. Six Arts (liuyi 六藝), which include the classics and manifold commentaries on them.

2. Various Masters (zhuzi 諸子), which include the writings of various thinkers for the most part from the pre-imperial period, including the well-known Mengzi, Laozi and Zhuangzi.

3. Poems and Rhapsodies (shifu 詩賦), in which we find various poetic works listed.

4. Military Writings (bingshu 兵書) with manuals on strategy and tactics in warfare.

5. Calculations and Methods (shushu 數術), which collects texts concerning occult or cosmological matters, such as almanacs, works on astrocalendrical science and divination.

6. Recipes and Techniques (fangji 方技), which is devoted to medical matters, including general medical writings, works on pharmacy, on techniques for the prolongation of life and on sexual practices.

\footnotetext{
also where the collection was kept. Archaeologists have identified the remains of the Pavilion, and this is not where the wooden slips were found. See the excavation report: Zhongguo shekeyuan kaogusuo 1996, 17-18, 238-248.

19 There is, of course, the possibility of copied manuscripts from the imperial collection being given to local dignitaries. In one case, a sealing clay (fengni) relating to the imperial collection was found in a tomb dated to the Western Han. It has been argued that the tomb's owner must have received manuscripts from the imperial collection. However, the excavation did not bring any manuscripts to light. All the manuscripts are thought to have rotted away. See Liu Zunyan/Liang Yong 2003.
}

20 For more exact numbers, see my dissertation: Fölster 2016, 72. 
The first three categories in particular may be readily identified as bringing together 'texts of tradition'. The latter three categories group texts of a more technical nature, which were certainly not administrative documents. The only entries seemingly related to the administrative realm are the Memorials with Opinions (Yizou 議 奏) found at the very end of each listing for four of the six classics. ${ }^{21}$ However, all of these are clearly linked to the famous scholarly debate about the meaning of the classics, which took place in 51 BCE at the Stone Ditch Pavilion (Shiquge 石渠閣). ${ }^{22}$ These are probably summaries of the different scholarly positions regarding the classics and not documents of the administrative machinery. There is yet another entry with the title Memorializing Matters (Zoushi 奏事). However, from an additional remark to this entry, it becomes clear that these are not administrative documents either, but rather acclaimed memorials and epigraphic texts from the Qin dynasty (221-207 BCE), the predecessor to that of the Han. ${ }^{23}$

What is not found in the Treatise is, in fact, more illuminating. Beginning with Wang Yinglin 王應麟 (1223-1296), Chinese scholars have noted that the collection was not all-encompassing. However, a thorough examination of the many titles identified as missing reveals that most of them are either variant titles, mere chapter titles of works found in the Treatise or later works attributed to men of the Former Han period..$^{24}$ Legal texts, or more precisely what is listed in later catalogues as Statues and Ordinances of the Han (Han lü 漢律, Han ling 漢令), are conspicuously missing. ${ }^{25}$ It is only through the manifold manuscripts excavated in recent decades that we have learnt more about the content and modus operandi of these statues and ordinances since they include many texts of this kind. ${ }^{26}$

Judging from the following statement in the History of the Han, the reason such texts were not included in the Treatise is simply that they were the responsibility of a special government agency and were thus kept in a separate place:

21 HS 30:1705, 1710, 1714, 1716.

22 The debate is mentioned in HS 73:3113, 88:3598. Also see Tjan 1949, 6.

23 HS 30:1714. Also see Fu Rongxian 2007, who equally argues that Liu Xiang did not work with administrative documents during the grand collating project.

24 Fölster 2016, 73-83, 197.

25 Jinshu 30:922.

26 The most authoritative publications in Western languages in this field are Lau/Lüdke 2012, and Barbieri-Low/Yates 2015. On legal manuscripts dated to the Qin dynasty, see Hulsewé 1985 and Staack/Lau 2016. 
今叔孫通所撰禮儀, 與律令同錄, 藏於理官, 法家又復不傳。27

Now the rites and ceremonies compiled by Shusun Tong (d. in 188 BCE) were recorded together with statutes and ordinances and stored at the regulatory office, and the legal experts ${ }^{28}$ did not transmit them again.

Unfortunately, we do not know much about the regulatory office. The seventhcentury commentary by Yan Shigu 顏師古 defines it as the 'legal office' (faguan 法官). ${ }^{29}$ In the Han period the term 'regulatory office' is said to be an unofficial name for the office administering lawsuits. ${ }^{30}$ Furthermore, it has been suggested that a sub-unit-the Bureau for the Direction of Legal Principles (dianfa cao 典法曹)-'probably organized and archived the voluminous written statutes and ordinances' ${ }^{31}$ Despite the details we have being rather scant, they suggest that there was a specific office responsible for storing statutes and ordinances. ${ }^{32}$

The fact that other administrative documents were also archived is mentioned in the Embellishments on the Heart of Writing (Wenxin diaolong 文心雕龍), a literary critique composed many centuries later by Liu Xie 劉照思 (c.465-c.521):

按七略、藝文, 謠詠必錄; 章表奏議, 經國之樞機, 然闒而不纂者, 乃各有故事, 布在 職司也。

We find included in the Seven Epitomes and the [Treatise on] Classics and other Texts records of all poetic writings; and yet the petitions, presentations, memorials, and opinions, all crucial in the conduct of government, are omitted, because they each were concerned with precedents and were kept in the files of government offices. ${ }^{33}$

This explanation follows the above distinction between literary texts on the one hand and administrative documents on the other quite closely.

27 HS 22:1035.

28 Judging from the context, these legal experts (fajia) are not the Legist Experts (fajia) under the Various Masters category of the Treatise (HS 30:1735-1736), but probably regulatory office staff. For the Later Han period, such legal experts are mentioned among the staff of the Director of the Imperial Clan (zongzheng); see Bielenstein 1980, 42.

29 HS 22:1035. In another commentary, Yan Shigu identifies the term to denote the staff of the Minister of Justice (sikou 司寇); see HS 23:1088.

30 Hucker 1985, 3618. For details about the offices, see Bielenstein 1980, 38.

31 Barbieri-Low/Yates 2015, 131.

32 In Mogens Weitemeyer's opinion, legal texts were kept in libraries (see above). This obviously was not the case in Han time China.

33 Wenxin diaolong, Zhangbiao 22, 5:243 (modified transl. of Shih 1959, 127). The term 'precedent' is discussed below. 
We may conclude that in terms of its content, the collection documented in the Treatise complies with the above definition of a library. The same may be said about the other criteria that are mentioned. The Treatise itself is evidence of a clear organization, even though we lack definite proof that it was also the basis for the physical organization of the manuscripts in the collection. As for the function of the collection, from the little we know about the collation project, which basically created the collection as we know it from the Treatise, the editorial reports address the emperor and were probably presented to him together with the respective work. Despite the reports' assessment of the texts' usefulness to the emperor-one could say they recommend what the emperor should read-the set phrase '[so that] this writing can be neatly copied (書可縍寫)' found at the end of the reports seems to imply that it should also serve to make further fair copies. ${ }^{34}$ However, there only is one reference attesting that the emperor did actually give away copies of manuscripts from his collection. ${ }^{35}$ Apart from producing further copies, the collection contained various duplicate texts to begin with. The identification and comparison of these duplicates was one of the main tasks in Liu Xiang's collation project. The few editorial reports we know of include the exact number of duplicates employed. This underpins Olaf Pedersén's argument about the library being a collection of works containing multiple copies of each text. Although the ostensible purpose was to create a collection of items for immediate and later use by the emperor, this 'library' evidently also served the scholarly community. The entire collation project was a scholarly endeavour involving not only Liu Xiang and his son, but many other men, about a dozen of whom we know by name. Certain people are conspicuously missing here, however: the Erudites (boshi 博士), i.e. the official court scholars appointed to academic chairs for the imperially acknowledged classics. ${ }^{36}$ This reinforces an accurate remark by Marcel Lepper, according to which libraries are places for the production and reproduction of texts and not predominantly places of safekeeping and registration. ${ }^{37}$

34 Fölster 2016, 84-87, 139.

35 HS 100A:4203. It is telling that the beneficiary of the emperor's gift was an ancestor of Ban $\mathrm{Gu}$, who was involved in the collation project. The manuscripts were kept within the family and the collection attracted scholars who came to view them; see HS 100A:4205.

36 See Fölster 2016, 133-139.

37 Lepper 2012, 66. 


\section{Archives of the Former Han}

As for the archives in the 'various organs of government', we unfortunately lack information that is as detailed as that in the Treatise; no substantial catalogue or inventory of the central archives has come down to us. However, it is clear that administrative documents were produced, circulated and probably stored in large quantities. This is simply due to the fact that the Han maintained an elaborate bureaucracy with more than 120,000 officials employed throughout the entire realm, which in turn was divided into 13 provinces, 103 commanderies and more than 1,500 county-level government units. ${ }^{38}$ That the task of storing such large amounts of documents created its own problems is evident from the following two statements about statutes and ordinances:

方今律令百有餘篇, 文章繁, 罪名重, 郡國用之疑惑, 或淺或深。自吏明習者, 不知所 處, 而況愚民！律令塵冨於棧閣, 吏不能遍睹, 而況於愚民乎！ ${ }^{39}$

Nowadays, the statues and ordinances amount to more than a hundred chapters. Their paragraphs are numerous and the offences [therein] repetitive, so the implementation in the commanderies and kingdoms has become uncertain and confused. Some [officials] have superficial [knowledge of the statues and ordinances], while others are very [knowledgeable about them]. If even well-versed officials do not know how to assess [statutes and ordinances], how much less would untaught people know! The statutes and ordinances lie in stacks gathering dust and get eaten by worms, [so many that] officials are unable to look at them all. How much less able would untaught people be!

及至孝武郎位, $[\cdots]$ 。律令凡三百五十九章, 大辟四百九條, 千八百八十二事, 死罪決 事比萬三千四百七十二事。文書盈於几閣, 典者不能徧睹。

Coming down to the time when [Emperor] Xiaowu (r. 141-87 BCE) ascended the throne, [...]. The Statutes and Ordinances [contained] in all 359 sections: for the death penalty 409 articles [covering] 1,882 cases, and 13,472 cases of judicial precedents for crimes [deserving] death. Writings and documents filled tables and cupboards and the officials in charge were unable to look at them all. ${ }^{40}$

38 The most authoritative study on the Han bureaucracy in a Western language is Bielenstein 1980. See Loewe 2006 for a less technical account. For briefer accounts, see Loewe 1986 and more recently Ding 2015.

39 Yantielun 55: Xingde, 10:566.

40 HS 23:1101 (modified transl. of Hulsewé 1955, 338). 
Statutes and ordinances were only one type of document. We can safely assume that the elaborate communication system used by the central administration created even larger numbers of documents, which probably involved frequent copying of documents for archival purposes. Imperial decisions handed down to the regions and provinces and certificates of appointment were probably copied, ${ }^{41}$ but there also is evidence that the imperial secretariat forwarded memorials to the emperor 'not in the original, but only in transcription, which was checked against its copy text'. ${ }^{42}$ Indirect evidence of archived documents existing is found in the ' $[r]$ eference to a precedence in the form of [...] (the rest shall be) like the ... precedent (它)如故事', a formula frequently found in various sources..$^{43}$ The imperial secretariat and other agencies probably routinely filed documents 'as precedents', ${ }^{44}$ which complies with Liu Xie's statement about 'petitions, presentations, memorials and opinions' being precedents 'kept in the files of government offices'. Further evidence of the practice of submitting multiple copies is also found in the History of the Han:

又故事諸上書者皆為二封, 署其一曰副, 領尚書者先發副封, 所言不善, 屏去不奏。

Another precedent was that all letters submitted to the throne had to be [presented] in duplicate. One of them was inscribed with the term 'duplicate copy'. The supervisor [of the affairs] of the imperial secretariat opened this copy first. If the wording was improper, it was rejected and not memorialized..$^{45}$

In fact, Wang Guihai argues that the final draft of an imperial instruction (zhao$s h u$ 詔書) was kept and filed away while copies of it were being sent out. ${ }^{46} \mathrm{He}$ also takes the term 'precedent' (gushi 故事) to mean archived documents in general. ${ }^{47}$ The actual meaning of the term gushi is somewhat more complicated, as Xing Yitian has discussed extensively: precedents 'were decisions, policies, or actions of the past that had been either incorporated into the legal code or otherwise constituted a usually esteemed and growing body of reference that could be used in order to argue for the re-enactment of a former political decision' ${ }^{48}$ Xing Yitian

41 Giele 2006, 208.

42 Giele 2006, 166.

43 Giele 2006, 239-245, quote 239.

44 Giele 2006, 242.

45 HS 74:3135 (modified transl. of Giele 2006, 67).

46 Loewe 2004, 530 mentions the possibility that two copies were made, a practice we know of from Tang times.

47 Wang Guihai 1999, 121-124.

48 Giele 2006, 239. Giele’s discussion is based on Xing Yitian 1987. 
further notes that gushi could also refer to conventions or practices that were not written down. ${ }^{49}$ Nonetheless, there is abundant evidence of the recourse to 'precedents' noted in writing: ${ }^{50}$ although evidence from the Later Han (25-220) far exceeds that from the Former Han, this 'may just be a simple reflection of the proportional increase of precedents', as Enno Giele says. ${ }^{51}$ Moreover, the continuous use of Former Han precedents during the Later Han period shows these documents must have been archived. The following example indicates that such documents were stored:

Wei Xiang 魏相, who served as chancellor from 67 to $59 \mathrm{BCE},{ }^{52}$ not only emphasizes the great importance of 'precedents', but also clearly makes use of them to support his argument in a memorial to the emperor.

好觀漢故事及便宜章奏, 以為古今異制, 方今務在奉行故事而已。數條漢興已來國家便 宜行事, 及賢臣賈誼、塦錯、董仲舒等所言, 奏請施行之, 曰: 《 $[\ldots]$ 臣相不能悉 陳, 昧死奏故事詔書凡二十三事。臣謹案王法必本於農[....]》

[Wei Xiang] delighted in looking up precedents of the Han and [former] memorials that had argued for expediencies. He was of the opinion that although the institutions of the past and present were different, one's duty today was merely to follow the precedents [of the past]. He frequently drew up accounts of the measures adopted by the government since the founding of the Han to meet expediencies as well as accounts of what eminent statesmen like Jia Yi, Chao Cuo, and Dong Zhongshu had stated, and submitted them to the throne with the request that they should be put into practice: '[...]. I cannot go into detail [here, but instead], risking capital punishment, I submit a total of twenty-three [former] edicts containing [or constituting] precedents [that may serve to illustrate my point]. [In sum,] I would like to state that the policies of the ruler must be rooted in [a desire to promote] agriculture $[\ldots] ., 53$

This clearly shows that officials resorted to documents constituting precedents. Hence, these documents must have been stored in some place. Xing Yitian even

49 He also points out various alternative terms used for the same phenomena; see Xing Yitian 1987, 336-338.

50 Xing Yitian 1987, 385-409 puts together all the cases of gushi he found in the relevant historical sources, presenting them in 12 categories. Tang Yongping 1990 includes a less extensive collection, differentiating between just three categories.

51 Giele 2006, 241.

52 For Wei Xiang's biography, see Loewe 2000, 578-579.

53 HS 74:3137-3138 (I have made use of previous translations by Giele 2006, 240 and Watson 1974, 180-181). Loewe 2004, 530 takes this as evidence that 'a complete file of decrees was included in the records and documents that were kept under the control of the Imperial Counsellor'. 
goes as far as to speak of a state archive (guojia dang'an 國家檔案) in this context. ${ }^{54}$ According to a commentary by Yan Shigu, the Recorders of Precedents (zhanggu 掌故) were the officials whose task it was to manage these precedents. ${ }^{55}$ However, it has been noted that at least from the reign of Emperor $\mathrm{Wu}$ onwards (141-87 BCE) there are no more examples mentioning the Recorders in connection with the precedents. In fact, all the textual evidence suggests that the officials at the Secretariat (shangshu 尚書) were in charge now. ${ }^{56}$ Members of the Secretariat are often described as being 'well versed in the precedents (明習故事)' ${ }^{57}$ The same holds true for the chancellors, like Wei Xiang, who was mentioned above. Another chancellor, when asked who should succeed him in office, recommended a man on the grounds that he 'had a clear understanding of the laws and knowledge of the state's precedents (明於法度, 曉國家故事)'. ${ }^{58}$

This may also be seen as an indication that not only the Secretariat kept copies of documents containing precedents. For the Later Han, at least, there is one case of a letter submitted to the throne, 'copies [of which] were forwarded to the Three Offices (移副三府). ${ }^{59}$ The term 'Three Offices' refers to the Three Excellencies (sangong 三公), denoting 'the three (or at times two) officials who stood at the most senior level of the [...] imperial administration'. During the Former Han, these were the Chancellor (chengxiang 丞相), Imperial Counsellor (yushi dafu 御 史大夫) and Supreme Commander (taiwei 太尉). In Later Han times, the Grand Minister of Works (da sikong 大司空) replaced the Imperial Counsellor and the Grand Minister over the Masses (da situ 大司徒) replaced the Chancellor. ${ }^{60}$ An epigraphic source dated to 169 CE corroborates this practice and mentions that the Senior Tutor (dafu 大傅) and the office of the Grand Minister of Agriculture ( $d a$ sinong 大司農) also received copies of a submitted letter. ${ }^{61}$

54 Xing Yitian 1987, 382.

55 HS 57B:2605. Also see Xing Yitian 1987, 349-350. I have followed the translation provided by Loewe 2000, 764. Bielenstein 1980, 207 translates it as ‘Authority on Ancient Matters', which I find rather misleading.

56 Xing Yitian 1987, 150, Tang Yongping 1990, 43. Yan Shigu tells us that the Recorders of Precedents were subordinate to the Grand Master of Ceremonies (taichang 太長) and therefore did not belong to the Secretariat. It is stated that there were a total of thirty Recorders of Precedents, but there is no reference on them for the Later Han; see Bielenstein 1980, $22,98$.

57 HHS 27:902. For further references, see Xing Yitian 1987, 354-356 and Tang Yongping 1990, 43.

58 HS 74:3148.

59 HHS 57:1851.

60 Loewe 2006, 19-20.

61 Lu xiang Shi Chen zou si Kongzi miao bei 魯相史晨奏祀孔子廟碑, in Quan Hou Hanwen 101:1019-1. 
During Emperor Cheng’s reign (33-7 BCE), Xue Xuan 薛宣 was recommended to the emperor as Imperial Counsellor. According to the History of the Han, 'the assessments of Xuan's achievements [were] recorded on bamboo slips in the two offices (宣考績功課, 簡在兩府)'. ${ }^{62}$ This seems to imply that the Chancellor's office and the Imperial Counsellor's office both kept records on the performance of officials. This is corroborated by an anecdote about Bing Ji 邴吉, who succeeded Wei Xiang as Chancellor and served in this position from 59 to $55 \mathrm{BCE} .{ }^{63} \mathrm{Bing} \mathrm{Ji}$ was known for treating his subordinates leniently. When one of his carriage drivers vomited on the cushions of a carriage, others immediately called for the driver to be dismissed. Bing Ji refused to do so, however. Not much later, the same carriage driver informed his master about an invasion at the frontier, which he had learnt about by pure chance. Since he was originally from the border provinces, he shared his knowledge with Bing Ji, making the following suggestion in the process:

《恐虜所入邊郡, 二千石長吏有老病不任兵馬者, 宜可豫視。》吉善其言, 召東曹案邊 長吏, 瑣科條其人。未已, 詔召丞相、御史, 問以虜所入郡吏, 吉具對。御史大夫卒遽 不能詳知, 以得譴讓。而吉見謂憂邊思職, 馭吏力也。

\begin{abstract}
'I'm afraid that in the border provinces where the barbarian invasions have taken place, the senior officials are in some cases too old and sickly to take up arms and ride a horse. It might be wise to make a preliminary check about the matter.' [Bing] Ji, approving this suggestion, ordered the clerk in charge of such matters to examine the files on the senior officials in the border provinces and make a detailed report on each man. Before the reports were completed, a command came from the emperor, summoning the Chancellor and the Imperial Counsellor into his presence, where he informed them of the barbarian invasion and asked about the officials in the provinces that were affected. Bing Ji gave him some very thorough answers, but the Imperial Counsellor, having been caught off guard, was unable to supply any detailed information himself and was reprimanded as a consequence. Bing Ji, on the other hand, was looked upon as a man who was truly concerned about the safety of the border and who paid close attention to the duties of this office - all because of the help his carriage driver had given him. ${ }^{64}$
\end{abstract}

The following account from the History of the Later Han (Hou Hanshu 後漢書) confirms the practice of keeping records about the performance of officials and shows that these also served as the basis for making decisions about personnel:

62 HS 83:3391. For details on Xue Xuan, see Loewe 2000, 628-629.

63 For more details on the biography of Bing Ji, see Loewe 2000, 12-13.

64 HS 74:3146 (modified transl. of Watson 1974, 191-192). 
舊制, 州牧奏二千石長吏不任位者, 事皆先下三公, 三公遣掾史案驗, 然後黜退。65

According to the old rules [of the Former Han?], if a regional commissioner proposed that a superior officer ranked 2000 bushels was not to serve in his post, the matter was sent to the Three Excellencies first, who would dispatch a Senior Clerk to check the records and investigate the case. [A superior officer] could only be discharged after that.

As for the places used for archives in the capital, precedents seem to have been stored in the Southern Palace (Nangong 南宮):

\section{弘前後所陳有補益王政者, 皆著之南宮, 以為故事。}

Every [suggestion] that [Zheng] Hong made at some point [during his career] to improve upon his ruler's policies was written down in [the files kept at] the Southern Palace [to serve as] precedents. $^{66}$

There is no mention of the Southern Palace during the Former Han period, though. Rather, the place most often identified as an archive by modern scholars is the Orchid Terrace (Lantai 蘭臺). ${ }^{67}$ The History of the Han mentions it simply as the office of one of the Secretary Assistants to the Imperial Counsellor, which was situated within the palace. This assistant 'was in charge of charts, registers and the secret writings (掌圖籍祕書) ${ }^{\prime}{ }^{68}$ It is not at all clear from this information whether it was also a place to archive documents permanently. Basing his knowledge on later sources, Hans Bielenstein remarks that this assistant 'passed on to the throne memorials from the Three Excellencies, the Nine Ministers, and the local administration, and transmitted imperial edicts addressed to commanderies and kingdoms' ${ }^{6}{ }^{6}$ Enno Giele argues that the men at this office 'were the central government's watchdogs who routinely screened memorials for offensive language. Or they were legal experts who were consulted to supply the policy makers with applicable legal arguments to decide either for or against a matter brought up from among the officials; or both' ${ }^{70}$ This rather suggests that the Orchid Terrace was an office to supervise the transmission of documents within the central bureaucracy.

65 HHS 33:1143.

66 HHS 33:1155 (modified transl. of Giele 2006, 240-241).

67 E.g. Zhou Xueheng 1994, 127. In the Later Han period, the other another prominent archive was the Eastern Tower (Dongguan 東觀).

68 HS 19A:725 (modified transl. of Dubs 2009, 23).

69 Bielenstein 1980, 9.

70 Giele 2006, 62. 
Moreover, the term 'secret writings' (mishu 祕書) is also used to denote those writings subject to Liu Xiang's collation project. ${ }^{71}$ Although the collation project dealt with anything but administrative documents, as we have seen above, the term 'secret writings' seems to refer to any writings found in the inner palace and thus directly related to the emperor. In his discussion of the history of the imperial collection, Liu Xin's Seven Epitomes (Qilüe) mentions that in 'the inner [palace] there are the repositories of the Pavilion of Perpetuation, the Spacious Interior and the Secret Chamber (內則有延閣、廣內、祕室之府) ${ }^{72}$ But since none of these place names occur elsewhere in the relevant sources, we cannot tell what kind of manuscripts were actually stored there.

Other important documents, such as those recording the enfeoffement of regional kings and other nobilities, are said to have been stored in what is called 'Stone Chamber and Metal Casket' (shishi jinkui 石室金貴):

\section{又與功臣剖符作誓, 丹書鐵契, 金貣石室, 藏之宗廟。}

With his meritorious followers [Liu Bang, the Han's founding emperor,] split tallies and made oaths, [recorded] in red writing on an iron certificate, [which were put in] a metal casket and a stone chamber, and kept in the ancestral temple. ${ }^{73}$

Keeping records of this kind in the ancestral temple seems to follow an earlier tradition. ${ }^{74}$ In any case, '[m]aintenance of an up-to-date list of the kings and nobles of the empire, and of the holders of other orders of honour (jue 爵), would seem to have been an essential duty of government, in the interests of controlling the administration of their estates and their exercise of their privileges' ${ }^{75}$ The fact that Liu Bang also consulted such a register is suggested in the following passage: 'When Gaozu (i.e. Liu Bang) reached Luoyang, he summoned all those who had attained [the rank of] marquis according to the register [...] (高祖至雒陽, 舉通侯籍召之 [...]) ${ }^{76}$ That this register was also maintained after Liu Bang's death can be seen in

71 HS 10:310: '[...] Liu Xiang collated the secret writings of the inner [palace] ([...] 劉向校中祕書)'. Also see HS 36:1950, 1967.

72 Quoted in HS 30:1702.

73 HS 1B:81 (modified transl. of Dubs 1938-1955, I:146).

74 See SJ 130:3319, which mentions these places when talking about the state of stored documents prior to the Han dynasty.

75 Loewe 2004, 253.

76 SJ 8:381 (modified transl. of Nienhauser 1994-, II:69). Loewe 2004, 319 suggests that this refers to a register going back to the Qin period, since Liu Bang had not conferred any ranks of honour yet at that time. 
the following imperial instruction from 187 BCE, which was promulgated by his widow, Empress Lü:

高皇帝匡飭天下, 諸有功者皆受分地為列侯, 萬民大安, 莫不受休德。朕思念至於久遠而 功名不著, 亡以尊大誼, 施後世。今欲差次列侯功以定朝位, 蔵于高廟, 世世勿絕, 嗣子 各襲其功位。其與列侯議定奏之。

The Emperor Gao[zu] reformed and ordered the world. All those who distinguished themselves received a share of its territory and were made marquises. All the people [now enjoy] great peace; not one who has not received of his bountiful virtue. We have been thinking and reflecting [on this matter]. If, in the distant future, their merits and names have not been made manifest, there will be nothing to honour their great conceptions and exhibit them [for the benefit of] later generations. Now [We] wish to classify and rank the merits of the marquises, so as to determine upon their positions in the court and preserve them in the Temple of Gao[zu] from generation to generation without end, so that their heirs may each inherit their merits and positions. Let [this matter] be discussed with the marquises, settled and memorialized [to $\mathrm{Us}] .^{77}$

Empress Lü's suggestion was met with approval by the marquises, so a register was stored in the temple of Gaozu accordingly. It is reported that Emperor Xuan (reigned 74-49 BCE) 'opened the treasuries attached to the shrines and had the old registers inspected (開廟蔵, 覽舊籍)' ${ }^{78}$ This shows that the register continued to be consulted. It was probably the Director of the Imperial Clan (zongzheng 宗正), who was responsible for keeping an up-to-date list of the kings and nobles of the empire belonging to the imperial clan. ${ }^{79}$ Records of other nobilities were presumably the responsibility of the Chief Commandant over the Nobility (zhujue zhongwei 主爵中尉).$^{80}$ At the same time, it has to be noted that the Treatise includes titles that may be identified as genealogies, probably containing similar information to what would be noted in the nobility register. How far this is related to the fact that Liu Xiang served as Director of the Imperial Clan earlier in his career is unclear, though. ${ }^{81}$

77 HS 3:96 (modified transl. of Dubs 1938-1955, I:194-195). Also see Loewe 2004, 320.

78 HS 16:528 (transl. by Loewe 2004, 253).

79 At least this is suggested by SJ 60:2118: 'The Director of the Imperial Clan is in charge of the register for the clan and all lesser members of the Liu [family] (宗正者, 主宗室諸劉屬籍)'. Also see Loewe 2004, 319.

80 Loewe 2004, 319. He also discusses the different changes in name and the institutional reforms related to this office. Also see Bielenstein 1980, 87. See Loewe 1997, 185 for an actual example of a certificate of bestowal of a rank of honour.

81 Judging from the titles, these seem to be rather historical or mythological genealogies predating Han times: Generational Chronologies of Emperors, Kings, and Feudal Lords (Diwang zhuhou shipu 帝王諸侯世譜), A Yearly Chronology of Emperors and Kings since Antiquity (Gulai 
Sima Qian 司馬遷 (145/135-86 BCE), compiler of the Records of the Grand Scribe (Shiji 史記), also names 'the writings of the Stone Chamber and Metal Casket' as some of his sources. ${ }^{82}$ Michael Loewe argues that the table of nobilities found in both the Records of the Grand Scribe and Ban Gu's History of the Han 'drew immediately from documents compiled in the course of imperial administration'. ${ }^{83}$ Although we cannot be absolutely sure whether Sima Qian was referring to the nobility registers when he mentioned the writings of the 'Stone Chamber and Metal Casket', there is no doubt that he and Ban $\mathrm{Gu}$ both made extensive use of administrative documents. This not only includes the registers, but imperial instructions or memorials to the emperor as well. ${ }^{84}$ Of course, we should not forget that all these are only 'abbreviated versions of original documents' and 'the results of a skilful selection', as Michael Loewe has put it. ${ }^{85}$ However, it would be wrong to assume that the main purpose of the archives was to preserve documents for writing history. ${ }^{86}$ None of the two histories were initiated by the central government. In fact, when the imperial court found out that Ban $\mathrm{Gu}$ was compiling a history, he was first imprisoned on the accusation that he 'privately altered and produced a state history (私改作國史)'; it was only after Ban Gu's work had been shown to the emperor that his compilation received imperial sanction. ${ }^{87}$

Finally, the 115 wooden slips mentioned above that were found in the remains of the Former Han capital, Chang'an, have been interpreted as part of an archive for documents on omens. ${ }^{88}$ They may have belonged to the Grand Scribe's collection (taishi 太史), who among other things was in charge of keeping record of portents and auspicious omens. ${ }^{89}$ For lack of any further information, this assumption remains speculative, though.

What are known as 'bone tags' (guqian 骨簽) are yet another case: around 60,000 of these items have been found among the remains of Chang'an, 57,000 with records inscribed on them. These seem to be inventories of tributes and goods (mostly weapons) produced by workshops outside the capital and presented to the

diwang nianpu 古來帝王年譜) and Origins of the Hereditary Houses (Shiben 世本); see HS 30:1714, 1766. Regarding Liu Xiang as Director of the Imperial Clan, see HS 19B:813, 36:1929. Also see Loewe 2004, 209-210.

82 SJ 130:3296.

83 Loewe 2004, 288.

84 For a detailed discussion of imperial decrees found in the two histories, see Loewe 2004, 524-546.

85 Loewe 2004, 528, 546.

86 See Wang Guihai 1999, 218.

87 HHS 40:1334. Also see Clark 2008, 20-25.

88 Xing Yitian 2011a, 140. Xing does not expressly use the term 'archive', but speaks of a 'storage place'.

89 Bielenstein 1980, 19. 
imperial court. 'The bone objects were found in piles close to the walls of the rooms, suggesting that they were once stacked on shelves or hung on racks. The objects seem to be of two complementary shapes, inscribed in two different formats. Some paired examples were bound loosely together at the time of excavation', says Anthony Barbieri-Low. ${ }^{90}$ It is thought that bone was used instead of wood or bamboo because it was more durable. Together with the fact that many of the records have serial numbers on them and that the dates recorded span much of the Former Han period, this appears to be an example of systematic storage. It therefore seems appropriate to speak of an archive here, which probably stored these tags to keep track of shipments and ensure the quality of the items that were to be delivered. ${ }^{91}$

\subsection{Local archives}

So far, we have only dealt with archives in the capital, but as already mentioned above, the administration permeated the realm all the way down to the local level. It was the county-level government units that provided the information necessary to govern an empire as extensive as that of the Former Han. The officials on the county level would send biannual reports to the next-highest level in the administration, the commandery. These reports provided basic information on the area, including 'figures for the registered population, the acreage of land newly put under the plough, the figures of both cash and grain received and disbursed and figures for the extent of crime'. ${ }^{92}$ Information from every county was gathered and processed by the commandery government before being sent to the capital once a year. This annual submission of accounts (shangii 上計) also included reports on the performance of officials, which would be used for decisions about their promotion or demotion. The processing of the reports on the central level was the responsibility of the Chancellor and his ministry. ${ }^{93}$ This was essential for the government since ' $[\mathrm{t}]$ he registers of population and land were necessary for the collection of tax and the conscription of men for service'. ${ }^{4}$ The population figures for the year $2 \mathrm{CE}$ recorded in the History of the Han, the earliest such data available for China, certainly must go back to the central register of the Chancellor,

90 Barbieri-Low 2001, 4. For more details see the excavation report: Zhongguo shekeyuan kaogusuo 1996, 91-122.

91 Zhongguo shekeyuan kaogusuo 1996, 122, Liu Guoneng 2007. For further interpretations on the function of the bone tags, see Barbieri-Low 2001, 4-5.

92 Loewe 2004, 44.

93 Bielenstein 1980, 8.

94 Loewe 1986, 483-484. 
which assembled all the information submitted from across the realm. ${ }^{95}$ It also seems likely that on returning to their commanderies, those officials who submitted the accounts in the capital 'would have taken with them copies of the latest decisions and orders of the government, in the form of decrees, statutes and ordinances, or the calendar that had been drawn for the ensuing year, ${ }^{96}$

It is clear that the many documents sent either way would have been archived at the various administrative levels. The manuscript finds of recent decades have brought examples of such documents to light. Take the manuscripts found in a tomb at Yinwan 尹灣 (Jiangsu), for instance, which include documents dated to the late Former Han period. Many of these have been identified as belonging to the annual procedure of submitting accounts to the central government. ${ }^{97}$ Another example is the slips and boards found in a well at Liye 里耶 (Hunan), which are believed to stem from a Qin dynasty county archive. ${ }^{98}$ It is well known-and not only from the Liye manuscripts-that the elaborate bureaucracy was not invented by the Han; they basically took over the system from their predecessors, the Qin dynasty. Furthermore, among the manuscripts found in a tomb in Shuihudi 睡虎地 (Hubei) dated to 217 BCE, there are statutes of the Qin in which we find the term shufu 書府 (lit. 'repository for writings'). Anthony F. P. Hulsewé has aptly translated this term as 'archive':

冊敢以火入藏 (藏) 府、書府中。吏已收藏（藏）, 官巫夫及吏夜更行官。册火, 乃閉 門戶。令令史循其廷府。節（即）新為吏舍, 冊依藏（藏）、書府。

One must not venture to enter storehouses or archives with fire. When the officials have finished collecting the stores, the Bailiff of the office and the officials take turns inspecting the office at night. If there is no fire, they close the doors. The Scribe Directors must be ordered to patrol the [Prefect's] office and the storehouses. In case of new construction of official hostels, these must not adjoin any storehouses or archives. ${ }^{99}$

More details on local archives can be found among the manuscripts containing Han statutes found in a tomb in Zhangjiashan 張家山 (Hubei) dated to 187 BCE. The 'Statutes on Households' (Hulü 户律) stipulate how local officials were to

95 HS 28A:1543-1603. Also see Bielenstein 1947, 135-139.

96 Loewe 2004, 44.

97 For a study on these documents in English, see Loewe 2004, 38-88.

98 Yates 2012/2013 offers a brief introduction to these manuscripts, which are still awaiting full publication. Also see Hsing 2014, 155-165. For details of further administrative documents found among manuscripts at other sites, see Hsing 2014, 165-184.

99 Shuihudi Qinmu zhujian zhengli xiaozu 1990, 64 (modified transl. of Hulsewé 1985, A105 (slips 97-98), 89). Xing Yitian 2011b, 19 points out some further sources mentioning special measures of fire protection, which were probably related to archives as well. 
handle the various registers containing the information that would eventually be submitted to the next-higher level in the administrative hierarchy:

民宅園戶籍、年細籍、田比地籍、田合籍、田租籍, 謹副上縣廷, 皆以筴若匣實盛, 緘 閉, 以令若丞、官嫱夫印封。獨別為府, 封府戶。節 (即) 有當治為者, 令史、吏主者 完封奏（湊）令若丞印。嗇夫發, 即雜治為。其【事】已, 輙復緘閉封藏（藏）。[...]

As for the ordinary people's household registers of their homesteads and grounds, the detailed age registers, the land registers indicating neighboring fields, the unified registers of agricultural fields, and the registers of their agricultural field taxes, carefully make copies and forward these up to the County Court, and, in every case, contain them in a bamboo chest or a wooden coffer, bound shut with cords, and seal [the chest or coffer] using the seal of the Magistrate, the Assistant Magistrate, or the Bailiff of the Office. Place them by themselves as a document archive and seal the door of the archive. When it is necessary to put some of the registers in order or create [new ones], the Scribe Director and the official in charge are to ensure that the seals are intact and to match [the impression] with the seal of the Magistrate or the Assistant Magistrate. Once the Bailiff [of the Office] has opened [the archive], they can then manage or create [registers] together. When the affair is complete, immediately bind shut [the archive] with cords, seal [it], and store [it] away once more. $[\ldots]{ }^{100}$

Although the term shufu is not employed in the statute, it is clear from the context that $f u$ 府 must refer to the county archive. ${ }^{101}$

\subsection{Physical organization of archives}

The Statutes on Households also show that the management of the documents implied some kind of organization. Evidence of the physical organization of documents in archives has also been noted among other manuscript findings. Among the documents found at Wuwei 武威 (Gansu) there is one bamboo manuscript that refers to ‘Orchid Terrace Ordinance no. 33 (蘭臺令第卅三)' and 'Secretariat of the Imperial Counsellor Ordinance no. 43 (御史令第冊三)'. ${ }^{102}$ In further bamboo slips found at the same site at a later time, there are more examples, such as 'the ordinance is at Orchid Terrace no. 43 (令在蘭臺第冊三)'. ${ }^{103}$ These numbers are considered to be serial numbers, which were probably used to file and retrieve archived documents.

100 Barbieri-Low/Yates 2015, Hulü 17, 798-799.

101 In an earlier translation of the same statute, Robin Yates actually translated it as 'document repository', not 'archive'; see Yates 2012/2013, 327.

102 Wang Guihai 1999, 218, 223; Gansu sheng bowuguan/Zhongguo kexueyuan kaogu yanjiusuo 2005, 140-141.

103 Wuwei xian bowuguan 1984, 35. 
Judging from the institutions mentioned, this obviously refers to documents archived in the capital. ${ }^{104}$ Evidence of the numbering of imperial ordinances can also be seen in the History of the Han. The term 'first ordinance (令甲)' is generally understood to refer to an enumeration system. ${ }^{105}$

Wang Guihai also takes some of the Juyan 居延 manuscripts, which were found at garrisons along the military defence lines in the north-west, to represent archives of the lowest unit, called 'company' (houguan 候官). ${ }^{106}$ 'Here officials maintained registers of the items that they dispatched or received, recording the name of the originator as seen in the seal, the contents or subject of the item, its date, the time taken for delivery and the names of the servicemen who had handled the process', says Michael Loewe. ${ }^{107}$ Among these manuscripts there are also numerous examples of labels referring to the time and content of documents, such as the following two:

\section{建始三年正月以來刺史書 ${ }^{108}$}

Letters of the Regional Inspector since the $1^{\text {st }}$ month of the $3^{\text {rd }}$ year of the Jianshi era (30 BCE) onwards

永始四年李敏自言書 109

Letters reported by Lin Min in person during the $4^{\text {th }}$ year of the Yongshi era (13 BCE)

The labels often come with a small hole in them, which was probably used to attach them to manuscripts for the purpose of creating files of documents on a certain subject and to facilitate their retrieval. ${ }^{110}$ Among the Juyan manuscripts there are also some examples of catalogues or file registers, which list the contents of imperial instructions (zhaoshu) together with a serial number:

104 Wang Guihai 1999, 218, 223. For a detailed discussion, see Wuwei xian bowuguan 1984, 51-53. 105 HS 8:252 (Dubs 1938-1955, II:227). According to later commentators, this refers to the numbering of the ordinances. Also see Wang Guihai 1999, 218.

106 Wang Guihai 1999, 223-227. Loewe 1997, 191 equally refers to the Juyan manuscripts as 'parts of official archives, drawn up in the course of administrating the empire'.

107 Loewe 2006, 110. For a brief discussion of the different kinds of documents among the Juyan manuscripts, see Loewe 1997, 177-191.

108 EPT50:182AB; see Gansu sheng bowuguan/Zhongguo kexueyuan lishi yanjiusuo 1990, 164.

109 EPT50:199; see Gansu sheng bowuguan/Zhongguo kexueyuan lishi yanjiusuo 1990, 164165. Also see Wang Guihai 1999, 204-206, who presents a list with a total of twelve labels of this kind. On the meaning of the legal term ziyan 自言, see Staack/Lau 2016, 154, n. 755.

110 Wang Guihai 1999, 211-213. 


\title{
縣置三老二 行水兼興船十二 置孝弟力田廿二 徵吏二千石以符卅二 郡國調列侯兵冊 二 年八十及孕朱需頌旉五十二
}

\begin{abstract}
'Prefectures establish Three Elders, no. 2; requisitioning of boats for traveling on water, no. 12; establishing the filial, brotherly, and strong farmers, no. 22; conscripting officials with [a nominal salary] of two thousand piculs with tallies, no. 32; commanderies and states transfer soldiers of the Marquis, no. 42; commoners eighty years old, pregnant women, and babies free from chaining, no. $52^{111}$
\end{abstract}

In other cases, there are further details on the time documents arrived. ${ }^{112}$ There are also examples of 'communication registers' recording the compilation and delivery of documents. The information in these includes 'summaries of the subject matter', 'names and titles of the originators and addresses' and records 'of the servicemen responsible for delivery and of the time that was taken'. ${ }^{113}$

It is evident that most of the documents that have been discovered are not cases of preserved archives, but rather remains of such-documents which were discarded at some point. The documents found among manuscripts in tombs, such as those from Zhangjiashan or Yinwan, are yet another problem, since there is no consensus among scholars about the question of why manuscripts were entombed in the first place. ${ }^{114}$ However, it seems very likely that they were not original documents, but rather copies made specifically for the purpose of burial. ${ }^{115}$

Based on the analysis of different layers in which around 3,000 discarded documents were found at Pochengzi 破城子 (Gansu), Wang Guihai surmises that archivists must have discarded documents that were no longer needed roughly once every thirteen years. It seems that these documents were burned or dumped in the immediate vicinity of the archive. At the same time, there are also plenty of examples of such documents being recycled for various purposes, including use as 'toilet paper' ${ }^{116} \mathrm{It}$ seems very likely that archivists at the central level of the administration also got rid of 'expired' documents regularly, but we lack explicit physical evidence of this.

111 Xie Guihua/Li Junming/Zhu Guozhao 1987, (5•3, 10•1, 13•8, 126•12), 7 (transl. by Li 2014, 81, n. 132). For a detailed study, see Chen Mengjia 1980, 275-285.

112 Xie Guihua/Li Junming/Zhu Guozhao 1987, (33•8), 51. Wang Guihai 1999, 213-215.

113 Loewe 1997, 178.

114 See Giele 2003, 428-431 for a general discussion of possible motives.

115 Hsing 2014, 177-178; Loewe 1997, 190-191.

116 Wang Guihai 1999, 227-232. Wang also mentions the administrative direction on the disposal of documents every three years stated in the Tang code, which might have antecedents in Han law. Also see Xing Yitian 2011b, 20-21. On recycling expired documents as 'toilet paper', see Hu Pingsheng 1996, 296-297. 
Not all manuscript finds outside tombs are necessarily discarded archive documents, though, as one might assume. ${ }^{117}$ The Liye manuscripts mentioned above were found in a well, which may seem like a clear case of them being discarded. Robin Yates, however, remarks that the layers in which the documents were found within the well do not show any clear temporal sequence; rather, he thinks that when the Qin dynasty started to collapse, the local archive was looted by the local population in an effort to cover up their massive debts recorded in administrative documents in the archive. ${ }^{118}$

\section{Conclusion}

My point of departure for this article on the distinction between 'library' and 'archive' in the Former Han dynasty was the imperial collection as it is presented in the Treatise on Classics and other Texts (Yiwenzhi). It is very clear that this collection constitutes a library and not an archive. The major points in distinguishing whether a collection is a library or archive are its content and function. As the Treatise shows us, the imperial collection only contains literary texts (in a broad sense); there are no administrative documents in it whatsoever. There is abundant evidence that the Han bureaucracy had archives for various government agencies on all levels of the administrative machinery, which were intended to store documents containing information that was needed. The archives played an important part in the smooth functioning of the bureaucracy and helped to ensure the empire could be governed properly. The imperial collection or library was apparently intended to serve the emperor. Nonetheless, it is evident from the grand collation project that the collection as we know it from the Treatise was the product of a scholarly endeavour involving the production and reproduction of a host of texts. It may be said that while the library was a place for scholarly and literary activities using its holdings, the many archives, on the other hand, stored documents produced, dispatched and employed by a bureaucratic apparatus, of which they were an essential part. Both institutions show a certain degree of organization so as to allow manuscripts to be located within the collections, otherwise we would have to speak of incidental assemblages of manuscripts. The Treatise, basically a classified catalogue, shows an obvious form of organization. In contrast, the evidence of archival organization is

117 Xing Yitian 2011a, 21, for instance, argues that the Liye manuscripts are discarded archive documents.

118 Xing Yitian 2011b, 21; Yates 2012/2013, 302-303, 327-328. 
very fragmentary. There is no fully preserved catalogue or inventory of an archive transmitted in the historical sources and the excavated documents are usually discarded files, which thus only yield a very fragmented picture of the organizational system.

Obviously, many archives existed in the Han period and they had already existed in the Qin period. This article has only dealt with one library, however: the imperial collection. One might ask whether the imperial collection was, in fact, the very first library in Chinese history (as some have already argued). We certainly know of numerous other collections: Emperor Wu's brother, Liu De 劉德 (d. in 130/129 BCE), who was enfeoffed as King Xian of Hejian 河間獻王 in 155 BCE, is said to have collected manuscripts on a large scale. ${ }^{119}$ From Liu Xiang's editorial reports we can tell that he made use of other manuscripts than those in the imperial collection, including manuscripts from the Grand Scribe (taishi) as well as some from his own (private?) collection. Finally, the Erudites (boshi 博士)-the official court scholars-certainly had manuscript collections of their own. In fact, the infamous burning of books ordered by the Qin's founding emperor explicitly excluded the manuscripts of the Erudites. ${ }^{120}$ However, there is no detailed information on the content of all these collections, let alone on their organization. It is because of this lack of information that the imperial collection of the Han is currently referred to as China's first library.

119 HS 53:2410-2411.

120 SJ 6:255. Also see Petersen 1995, 5-12. 


\section{References}

Amelung, Iwo, Joachim Kurtz, and Michael Lackner (eds) (2001), New Terms for New Ideas, Western Knowledge and Lexical Change in Late Imperial China (Sinica Leidensia, 52), Leiden: Brill.

Barbieri-Low, Anthony J., and Robin D. S. Yates (2015), Law, State, and Society in Early Imperial China. A study with critical edition and translation of the legal texts from Zhangjiashan tomb no. 247 (Sinica Leidensia, 126), 2 vols, Leiden, Boston: Brill.

Barbieri-Low, Anthony J. (2001), The Organization of Imperial Workshops during the Han Dynasty. $\mathrm{PhD}$ dissertation. Princeton University, Princeton.

Bielenstein, Hans (1947), 'The Census of China during the period 2-742 A.D.', in Bulletin of the Museum of Far Eastern Antiquities, 19, 125-163.

Bielenstein, Hans (1959), The Restoration of the Han Dynasty, Volume II. The Civil War. Reprint from the Museum of Far Eastern Antiquities Bulletin No. 31, Göteborg: Elanders.

Bielenstein, Hans (1980), The Bureaucracy of Han Times (Cambridge studies in Chinese history, literature, and institutions), Cambridge, New York: Cambridge University Press.

Brosius, Maria (2003), 'Ancient Archives and Concepts of Record-Keeping. An Introduction', in Maria Brosius (ed.), Ancient Archives and Archival Traditions, Oxford: Oxford University Press, 1-16.

Chen Mengjia 陳夢家 (1980), Hanjian zhuishu 漢簡緅述, Beijing: Zhonghua shuju 中華書局.

Chiang, Fu-tsung 蔣復璁 (1963), 'Handai de tushuguan 漢代的圖書館', in Dalu zazhi 大陸雜誌, 27/8:33-36, 9:31-34, 10:30-35.

Clark, Anthony E. (2008), Ban Gu's History of Early China, Amherst NY: Cambria Press.

Delhey, Martin, Vito Lorusso et al. (2015), Wordlists for Libraries and Closely Related Phenomena in Different Manuscript Cultures from Asia, Africa and Europe (CSMC - Occasional Paper, 2). https://www.manuscript-cultures.uni-hamburg.de/papers/CSMC_Occasional_Paper_2_Delhey_Lorusso_et_al.pdf (viewed on 26/09/16).

Di Chongde 狄蘢德, and Chen Bolan 陳伯蘭 (1981), 'Lunshu dang’an shiye he tushuguan shiye zai lishi shang de qubie 論述檔案事業和圖書館事業在歷史上的區別', in Dang'an gongzuo 檔案工作, 3, 56-57, 61 .

Ding, Xinzhao (2015), 'The Han Bureaucracy, Its Origin, Nature, and Development', in Walter Scheidel (ed.), State Power in Ancient China and Rome, Oxford: Oxford University Press, 56-89.

Drège, Jean-Pierre (1991), Les bibliothèques en Chine au temps des manuscrits, Jusqu'au Xe siècle (Publications de l'Ecole française d'Extrême-Orient, 161), Paris: École française d'Extrême-Orient

Dubs, Homer H. (1938-1955), The History of the Former Han Dynasty, 3 vols, Baltimore: Waverly.

Dubs, Homer H. (2009), The History of the Former Han Dynasty, Introduction to the 'Tables of the Hundred Officials' In the Ch'ien Han-shu 19A. https://library.uoregon.edu/ec/easia/read/Dubs_Vol_IV.pdf (viewed on 1/11/16).

Dudbridge, Glen (2000), Lost Books of Medieval China, London: British Library (The Panizzi lectures).

Fitzgerald, Devin (2015), 'Between Paper and Wood, or the Manchu Invention of the Dang'an', in Saksaha: A Journal of Manchu Studies, 13, 75-80.

Fölster, Max Jakob (2016), The Imperial Collection of the Former Han and the Origins of Philology in China. A Study of the Bielu, Qilüe and Hanshu Yiwenzhi. PhD dissertation. Universität Hamburg, Hamburg. 
Fu Rongxian 傅榮賢 (2007), 'Lun Liu Xiang wenxian zhengli de duixiang shi tushu er bu shi dang'an 論劉向文獻整理的對象是圖書而不是檔案’, in Dang'an guanli 檔案管理, 6, 35-37.

Gansu sheng bowuguan 甘肅省博物館, and Zhongguo kexueyuan lishi yanjiusuo 中國科學院历史\# 研究所 (eds) (1990), Juyan xin jian 居延新簡, Jiaqu houguan yu di si sui 甲渠候官與第四燧, Beijing: Wenwu chubanshe 文物出版社.

Gansu sheng bowuguan 甘肅省博物館, and Zhongguo kexueyuan kaogu yanjiusuo 中國科學\# 院考古研究所 (eds) (2005), Wuwei Han jian 武威漢簡, Beijing: Zhonghua shuju 中華書局 (Kaoguxue zhuankan 考古學專刊, Yi zhong di shier hao 乙種第十二號).

Giele, Enno (2003), 'Using Early Chinese Manuscripts as Historical Source Materials', in Monumenta Serica, 51, 409-438.

Giele, Enno (2006), Imperial Decision-Making and Communication in Early China. A Study of Cai Yong's Duduan, Wiesbaden: Harrassowitz.

Harris, Michael H., and Elmer D. Johnson (1999), History of Libraries in the Western World. 4th ed., Lanham, Maryland and London: Scarecrow Press.

Herbert, P. A. (1980), 'From Shuku to Tushuguan. An Historical Overview of the Organisation and Function of Libraries in China', in Papers on Far Eastern History, 22, 93-121.

HHS = Hou Hanshu 後漢書, Beijing: Zhonghua shuju 中華書局, 1973.

HS = Hanshu 漢書, Beijing: Zhonghua shuju 中華書局, 1962.

Hsing, I-tien (= Xing Yitian 邢義田) (2014), 'Qin-Han Census and Tax and Corvée Administration. Notes on newly discovered materials'. Transl. by Hsieh Mei-yu and William G. Crowell, in Yuri Pines, Gideon Shelach, Lothar von Falkenhausen and Robin D. S. Yates (eds), Birth of an Empire. The State of Qin Revisited (New perspectives on Chinese culture and society, 5), Berkeley, Los Angeles, London: Global Area and International Archive University of California Press, 155-186.

Hu Pingsheng 胡平生 (1996), 'Dunhuang Maquanwan jian zhong guanyu xiyu shiliao de bianzheng 敦煌馬圈灣簡中關於西域史料的讋證, in Wu Rongzeng 吳榮曾 (ed.), Jinxin ji: Zhang Zhenglang xiansheng bashi qingshou wenji 盡心集: 張政烺先生十八慶壽文集, Beijing: Zhongguo shehui kexue chubanshe 中國社會科學出版社, 273-297.

Huang Caigeng 黄才庚 (1988), 'Liang Han shiqi de dang'an yu dang’an gongzuo 兩漢時期的檔 案與檔案工作', in Zhejiang dang'an 浙江檔案, 8, 19-21.

Hucker, Charles O. (1985), A Dictionary of Official Titles in Imperial China, Stanford, California: Stanford University Press.

Hulsewé, Anthony F. P. (1955), Remnants of Han Law, Vol. 1: Introductory studies and an annotated translation of chapters 22 and 23 of the History of the Former Han Dynasty (Sinica Leidensia, 9), Leiden: Brill.

Hulsewé, Anthony F. P. (1985), Remnants of Ch'in Law. An annotated translation of the Ch'in legal and administrative rules of the $3^{\text {rd }}$ century B.C., discovered in Yün-meng Prefecture, Hu-pei Province, in 1975 (Sinica Leidensia, 17), Leiden: Brill.

Jacob, Christian (1998), 'Vers une histoire comparée des bibliothèques: Questions préliminaires, entre Grèce et Chine anciennes', in Quaderni di Storia, 48, 87-122.

Jinshu 晉書, Beijing: Zhonghua shuju 中華書局, 1974.

Koh Thong-ngee (1964), 'The Beginning of Chinese Bibliography, A Study of the Record of Literature in the History of the Former Han Dynasty', in Ts'e-fu, The Repository, 7/8, 26-41.

Lau, Ulrich, and Michael Lüdke (2012), Exemplarische Rechtsfälle vom Beginn der Han Dynastie. Eine kommentierte Übersetzung des Zouyanshu aus Zhangjiashan/Provinz Hubei 
(Study of languages and cultures of Asia and Africa monograph series, 50), Tokyo: Research Institute for the Languages and Cultures of Asia and Africa (ILCAA), Tokyo University of Foreign Studies.

Lepper, Marcel (2012), Philologie zur Einführung, Hamburg: Junius Hamburg.

Lewis, Mark Edward (1999), Writing and Authority in Early China, Albany N.Y.: State University of New York Press (SUNY series in Chinese philosophy and culture).

Li Deyun 李德運 (1980), ‘Xihan wangchao de dang’an ku 西漢王朝的檔案庫, Tianluge he shiquge 天祿閣和石渠閣', in Dang'an gongzuo 檔案工作 1, n. pag.

Li, Jingrong (2014), The Ernian lü ling Manuscript. PhD dissertation. Universität Hamburg, Hamburg.

Liu Guoneng 劉國能 (2007), 'Wo guo zui zao de zhuanmen dang'an guanku-Handai guqian dang'an guanku 我國昨早的專門檔案庫一漢代骨簽檔案館庫', in Zhongguo dang'an 中國 檔案, 7, 50-52.

Liu Zunyan 劉尊志, and Liang Yong 梁勇 (2003), “Xuzhou chutu “mifu” fengni de fengzhen fangfa qianxi 徐州出土「祕府」封泥的封緘方法淺析’, in Huaxia kaogu 華夏考古, 3, 96.

Loewe, Michael (1986), 'The Structure and Practice Government', in Denis C. Twitchett and John King Fairbank (eds), The Cambridge History of China, Vol. 1: The Ch'in and Han Empires, 221 B.C.-A.D. 220, Cambridge: Cambridge University Press, 463-490.

Loewe, Michael (1997), 'Wood and Bamboo Administrative Documents of the Han Period', in Edward L. Shaughnessy (ed.), New Sources of Early Chinese History. An Introduction to the Reading of Inscriptions and Manuscripts, Berkeley: The Society of the Study of Early China, The Institute of East Asian Studies, University of California, Berkeley, 159-192.

Loewe, Michael (2000), A Biographical Dictionary of the Qin, Former Han and Xin Periods (221 $B C-A D$ 24) (Handbook of Oriental Studies. Section 4 China, 16), Leiden: Brill.

Loewe, Michael (2004), The Men Who Governed Han China. Companion to A Biographical Dictionary of the Qin, Former Han and Xin Periods (Handbook of Oriental Studies. Section 4 China, 17), Leiden, Boston: Brill.

Loewe, Michael (2006), The Government of the Qin and Han Empires, 221 BCE-220 CE, Indianapolis, Ind.: Hackett.

Lu Hesheng 盧荷生 (1983), 'Handai de tushuguan shiye 漢代的圖書館事業’, in Furen xuezhi 輔仁學志 12, 417-439.

Nienhauser, William H. (ed.) (1994-), The Grand Scribe's Records, 9 vols, Bloomington: Indiana University Press.

Nylan, Michael (2014), 'Manuscript culture in late Western Han, and the implications for authors and authority', in Journal of Chinese Literature and Culture 1/1-2, 155-185.

Pedersén, Olof (1998), Archives and Libraries in the Ancient Near East, 1500-300 B.C, Bethesda, Md.: CDL Press.

Petersen, Jens Østergard (1995), 'Which books did the first emperor of Ch'in burn? On the meaning of pai chia in early Chinese sources', in Monumenta Serica, 43, 1-52.

Quan Hou Hanwen 全後漢文, in Quan Shanggu Sandai Qin Han Sanguo Liuchao wen 全上古三代秦漢三國六朝文, Yan Kejun 嚴可均 (ed.), Shanghai: Zhonghua shuju 中華書局, 1965.

Ren Jiyu 任繼愈 (ed.) (2001), Zhongguo cangshulou 中國藏書樓, 3 vols, Shenyang: Liaoning renmin chubanshe 遼寧人民出版社.

Shih, Vincent Yu-chung (1959), The Literary Mind and the Carving of Dragons. A Study of Thought and Pattern in Chinese Literature, New York: Columbia University Press.

Shuihudi Qinmu zhujian zhengli xiaozu 睡虎地秦墓竹簡整理小組 (1990), Shuihudi Qinmu zhujian 睡虎地秦墓竹簡, 北京: Wenwu chubanshe 文物出版社. 
SJ = Shiji 史記, Beijing: Zhonghua shuju 中華書局, 1982.

Staack, Thies, and Ulrich Lau (2016), Legal Practice in the Formative Stages of the Chinese Empire. An annotated translation of the exemplary Qin criminal cases from the Yuelu Academy collection (Sinica Leidensia, volume 130), Leiden, Boston: Brill.

Tang Yongping 唐永平 (1990), ‘Liang Han gushi dang'an kao 兩漢故事檔案考', in Dang'an guanli 檔案管理, 3, 41-44.

Tjan, Tjoe Som (1949), Po Hu T'ung, The Comprehensive Discussions in the White Tiger Hall, Vol. 1 (Sinica Leidensia, 6), Leiden: Brill.

Wagner, Vivian (2004), 'Archive am chinesischen Kaiserhof: Geheime Arsenale im Dienste dynastischer Erinnerungspolitik', in Archivalische Zeitschrift, 86/1, 9-90.

Wagner, Vivian (2006), Erinnerungsverwaltung in China. Staatsarchive und Politik in der Volksrepublik (Beiträge zur Geschichtskultur, 31), Cologne: Böhlau.

Wang Guihai 王桂海 (1999), Handai guan wenshu zhidu 漢代官文書制度, Nanning: Guangxi jiaoyu chubanshe 廣西教育出版社.

Wang Qiming 汪啟明 (2003), ‘Handai de tushu he tushuguan 漢代的圖書和圖書館’, in Wang Qiming 汪啟明 (ed.), Han xiaoxue wenxian yuyan yanjiu conggao 漢小學文獻語言研究\# 叢稿, Chengdu: Bashu shushe 巴蜀書社, 304-309.

Watson, Burton (1974), Courtier and Commoner in Ancient China: Selections from the History of the Former Han, New York: Columbia University Press.

Weitemeyer, Mogens (1956), 'Archive and Library Technique in Ancient Mesopotamia', in Libri, 6/3, 217-238.

Wenxin diaolong $=$ Wenxin diaolong zhushi 文心雕龍注释, Beijing: Renmin wenxue chubanshe 人民文學出版社, 1981.

Wu Xi 吳睎 (1996), Cong cangshu lou dao tushuguan 從藏書樓到圖書館, Beijing: Beijing tushuguan chubanshe 北京圖書館出版社.

Wuwei xian bowuguan 武威縣博物館 (1984), “Wuwei xin chutu Wang Zhang zhaoling ce 武威新 出土王杖詔令冊', in Gansu sheng wenwu gongzuodui 甘肅省文物工作隊 and Gansu sheng bowuguan 甘肅省博物館 (eds), Han jian yanjiu wenji 漢簡研究文集, Lanzhou: Gansu renmin chubanshe 甘肅人民出版社, 34-61.

Xie Guihua 謝桂華, Li Junming 李均明, and Zhu Guozhao 朱國炤 (eds) (1987), Juyan Han jian shiwen hejiao 居延漢簡釋文合校, 2 vols, Beijing: Wenwu chubanshe 文物出版社 (Qing Han Wei Jin chutu wenxian 秦漢魏晉出土文獻).

Xie Zhuohua 謝灼華 (2005), Zhongguo tushu he tushuguan shi 中國圖書和圖書館史, Wuhan: Wuhan daxue chubanshe 武漢大學出版社.

Xing Yitian 邢義田 (1987), “Cong “ru gushi” he “bianyi congshi” kan Handai xingzheng zhong de jingchang yu quanbian 從「如故事」和「便宜從事」看漢代行政中的經常與權變”, in Xing Yitian 邢義田 (ed.), Qin Han shi lungao 秦漢史論稿, Taibei: Dongda tushu gongsi 東 大圖書公司, 333-409.

Xing Yitian 邢義田 (2011a), 'Han Chang'an Weiyanggong qiandian yizhi chutu mujian de xingzhi 漢長安末央宮前殿遺址出土木簡的性質', in Xing Yitian 邢義田 (ed.), Di bu ai bao 地不愛寶. Handai de jiandu 漢代的簡牘, Beijing: Zhonghua shuju 中華書局, 138-143.

Xing Yitian 邢義田 (2011b), ‘Handai jiandu de tiji, zhongliang he shiyong 漢代簡牘的體積、重 量和使用, Yi zhongyanyuan shiyusuo cang Juyan Han jian wei li 以中研院史語所藏居延漢 簡為例', in Xing Yitian 邢義田 (ed.), Di bu ai bao 地不愛寶. Handai de jiandu 漢代的簡牘, Beijing: Zhonghua shuju 中華書局, 1-50. 
Yang, Shao-yun (2015), 'The Politics of Omenology in Chengdi's Reign', in Michael Nylan and Griet Vankeerberghen (eds), Chang'an 26 BCE. An Augustan Age in China, Seattle: University of Washington Press, 323-346.

Yantielun = Yantielun jiaozhu 鹽鐵論校注, Beijing: Zhonghua shuju 中華書局, 1992 (Xinbian zhuzi jicheng 新編諸子集成).

Yates, Robin D. S. (2012/2013), 'The Qin Slips and Boards from Well No. 1, Liye, Hunan. A Brief Introduction to the Qin Qianling County Archives', in Early China, 35-36, 291-329.

Ye, Wa, and Joseph W. Esherick (1996), Chinese Archives. An Introductory Guide (China research monograph, 45), Berkeley, California: Inst. of East Asian Studies University of California Berkeley Center for Chinese Studies

Zhang Wei 張偉 (1992), ‘Shidai jishi 時代紀實, Liang Han de guojia dang’an jigou 兩漢的國家檔 案機構', in Shanghai dang'an gongzuo 上海檔案工作 4, 48-50.

Zhang, Wenxia (2004), 'A Brief History of the Chinese Imperial Archives and Its Administration', in Journal of Archival Organization, 2, 17-38.

Zhao Zhiqiang 趙志強 (2016), “'Dang'an” ciyuan kaobian「檔案」詞源考辨’, in Dang'an xue tongxun 檔案學通訊, 4, 27-30.

Zhongguo shekeyuan kaogusuo 中國社科院考古所 (ed.) (1996), Han Chang'an Weiyanggong 漢長安城未央宮, 1980-1989 nian kaogu fajue baogao 1980-1989 年考古發掘報告, 2 vols, Beijing: Zhongguo shekeyuan 中國社科院.

Zhou Xueheng 周雪恒 (1994), Zhongguo dang'an shiye shi 中國檔案事業史, Beijing: Zhongguo renmin daxue chubanshe 中國人民大學出版社.

Zou Jiawei 鄒家煒, and Dong Jian 董儉 (1985), Zhongguo dang'an shiye jianshi 中國檔案事業簡史, Beijing: Zhongguo renmin daxue chubanshe 中國人民大學出版社. 